\title{
Letter to the Editor: 25(OH) Vitamin D3 and Early Neonatal Hypocalcemia in Preterm Infants
}

\author{
COSTANTINO ROMAGNOLI, ENRICO ZECCA, AND GIUSEPPE TORTOROLO
}

Department of Pediatrics, Catholic University of the Sacred Heart, Rome, Italy

Salle et al. (1) reported the use of vitamin D and its metabolites in premature infants. We were impressed both by the very low plasma calcium levels and by the high incidence of early hypocalcemia reported from the authors.

We studied the effect of oral administration of $25(\mathrm{OH})$ vitamin D3 (10 $\mu$ g daily, for the first wk of life) on plasma calcium levels of preterm babies with clinical characteristics similar to Salle's ones.

Our data given in the following table, of late hypocalcemia, strictly depending on intestinal calcium absorption, in the small for gestational age full-term infants (treated with $10 \mu \mathrm{g} /$ daily of $25-(\mathrm{OH})$ vitamin D3, 0:45 and controls, $4: 38=10.5 \% ; P<0.05)(5)$.

We think that if $25(\mathrm{OH})$ vitamin $\mathrm{D} 3$ is not a primary pathogenetic factor in the early hypocalcemia of premature infants, it is still unjustified to dismiss the pharmacologic action of this metabolite of vitamin $\mathrm{D}$. When administered with different prophylactic patterns (6), it could be useful and aid in the prevention of early

\begin{tabular}{|c|c|c|c|c|c|c|c|c|c|c|c|}
\hline & & $\begin{array}{l}\text { Gestational age } \\
\text { (wk) }\end{array}$ & $\begin{array}{c}\text { Body weight } \\
\text { (g.) }\end{array}$ & & & Daily & $\begin{array}{c}\text { plasma Ca } \\
(\mathrm{mg} / \mathrm{dl})\end{array}$ & levels & & & $\begin{array}{l}\text { Incidence of } \\
\text { early hypo- } \\
\text { calcemia }\end{array}$ \\
\hline & & $N^{\circ}$ & mean $\pm S . D$ & mean \pm S.D & $1^{\circ}$ & $2^{\circ}$ & $3^{\circ}$ & $4^{\circ}$ & $5^{\circ}$ & $6^{\circ}$ & $7^{\circ}$ \\
\hline Controls & 25 & $34.2 \pm 1.4$ & $2029 \pm 370$ & $8.9 \pm 0.8$ & $8.1 \pm 0.7$ & $8.1 \pm 0.8$ & $8.3 \pm 0.7$ & $8.6 \pm 0.7$ & $8.5 \pm 0.8$ & $9.1 \pm 0.8$ & $\begin{array}{c}3: 25 \\
(12 \%)\end{array}$ \\
\hline Treated & 34 & $34.7 \pm 1.4$ & $2146 \pm 373$ & $8.8 \pm 0.9$ & $8.1 \pm 0.9$ & $8.1 \pm 0.9$ & $8.3 \pm 1.0$ & $8.4 \pm 1.0$ & $8.9 \pm 1.0$ & $9.1 \pm 1.0$ & $\begin{array}{l}3: 33 \\
(9 \%)\end{array}$ \\
\hline
\end{tabular}

show that $25(\mathrm{OH})$ vitamin $\mathrm{D} 3$ was not able to modify significantly the daily mean plasma calcium levels in premature infants. But we observed a decrease in the incidence of early hypocalcemia, though this difference was not significant.

Comparing our data with that of Salle, we would emphasize that the higher mean plasma calcium levels and the lower incidence of early hypocalcemia probably depend on feeding pattern: human or humanized milk was commenced at $1 \mathrm{~h}$ of age in all our infants.

In fact, in a previous experience we pointed out that the incidence of hypocalcemia decreased from $48.02 \%$ in preterm infants in whom a milk diet was commenced at $6-12 \mathrm{~h}$ of age, to $22.58 \%$ in premature infants fed with humanized milk at $1 \mathrm{~h}(P$ $<0.01)(2)$.

We really think that early oral calcium administration is a primary factor in neonatal calcium metabolism and, therfore, in early neonatal hypocalcemia. $25(\mathrm{OH})$ Vitamin D3 certainly increases the intestinal calcium transport and absorption $(3,4)$. We also found that this metabolite of vitamin $D$ reduces the incidence hypocalcemia in such premature infants.

Hoping our data could be useful to a better understanding of the problem, we look for your answer.

\section{REFERENCES AND NOTES}

1. Salle, B., David, L., Glorieux, F. H., Delvin, E., Senterre, J., and Renaud, H.: Early oral administration of Vitamin $\mathrm{D}$ and its metabolites in premature neonates. Effect on mineral homeostasis. Pediatr. Res., 16: 75 (1982)

2. Romagnoli, C., Curro, V., Cataldi, L., Zuppa, A. A., Zecca, E., Pesaresi, M. A., and Tortorolo, G.: L'alimentazione precoce nella prevenzione delle cause metaboliche neonatali di handicaps. Data in press.

3. Chan, G. M., Tsang, R. C., Chen, I-W., Deluca, H. F., and Steichen, J. J.: The effect of $1,25(\mathrm{OH}) 2$ vitamin $\mathrm{D} 3$ supplementation in premature infants. $J$. Pediatr., 93: 91 (1978).

4. Alix, D., Riche, C., Morin, J. F., Broux, F., Rolland, J., and Castel, Y.: Traitement par le 25 hydroxycholecalciferol de l'hypocalcemie neonatale precoce dand un service de reanimation. Pediatrie, 33: 567 (1978).

5. Romagnoli, C., Zecca E., De Carolis, M. P., and Tortorolo, G.: unpublished data

6. Fleischman, A. R., Rosen, J. F., and Nathenson, G.: 25-hydroxycholecalciferol for early neonatal hypocalcemia. Occurrence in premature newborns. Am. J. Dis. Child., 132: 973 (1978) 